\title{
Inhibitory Effects of the Macrolide Antimicrobial Tylosin on Anaerobic Treatment
}

\author{
Toshio Shimada, ${ }^{1}$ Julie L. Zilles, ${ }^{1}$ Eberhard Morgenroth, ${ }^{1}$ Lutgarde Raskin ${ }^{2}$ \\ ${ }^{l}$ Department of Civil and Environmental Engineering, \\ University of Illinois at Urbana-Champaign, Urbana, Illinois \\ ${ }^{2}$ Department of Civil and Environmental Engineering, University of Michigan, \\ 107 EWRE Building, 1351 Beal Ave, Ann Arbor, Michigan 48109-2125; \\ telephone: 734-647-6920; fax: 734-763-2275; e-mail: raskin@umich.edu
}

Received 21 November 2007; revision received 13 February 2008; accepted 20 February 2008

Published online 7 March 2008 in Wiley InterScience (www.interscience.wiley.com). DOI 10.1002/bit.21864

\begin{abstract}
A laboratory-scale anaerobic sequencing batch reactor (ASBR) was operated using a glucose-based synthetic wastewater to study the effects of tylosin, a macrolide antimicrobial commonly used in swine production, on treatment performance. The experimental period was divided into three consecutive phases with different influent tylosin concentrations $(0,1.67$, and $167 \mathrm{mg} / \mathrm{L})$. The addition of $1.67 \mathrm{mg} / \mathrm{L}$ tylosin to the reactor had negligible effects on the overall treatment performance, that is, total methane production and effluent chemical oxygen demand did not change significantly $(P<0.05)$, yet analyses of individual ASBR cycles revealed a decrease in the rates of both methane production and propionate uptake after tylosin was added. The addition of $167 \mathrm{mg} / \mathrm{L}$ tylosin to the reactor resulted in a gradual decrease in methane production and the accumulation of propionate and acetate. Subsequent inhibition of methanogenesis was attributed to a decrease in the $\mathrm{pH}$ of the reactor. After the addition of $167 \mathrm{mg} / \mathrm{L}$ tylosin to the reactor, an initial decrease in the rate of glucose uptake during the ASBR cycle followed by a gradual recovery was observed. In batch tests, the specific biogas production with the substrate butyrate was completely inhibited in the presence of tylosin. This study indicated that tylosin inhibited propionateand butyrate-oxidizing syntrophic bacteria and fermenting bacteria resulting in unfavorable effects on methanogenesis. Biotechnol. Bioeng. 2008;101: 73-82.

(C) 2008 Wiley Periodicals, Inc.
\end{abstract}

KEYWORDS: anaerobic; antimicrobial; macrolide; methanogenesis; SBR; tylosin

\section{Introduction}

Antimicrobials used for therapy, prophylaxis, and/or growth promotion in confined animal operations have

Correspondence to: L. Raskin

Contract grant sponsor: U.S. Department of Agriculture under Cooperative Agreement Contract grant number: AG 58-3620-1-179 been detected in manure and treatment lagoons (Campagnolo et al., 2002; Hamscher et al., 2002; Zilles et al., 2005). The effects of different levels of antimicrobial usage on anaerobic waste treatment performance have been reported in only a few studies. For example, Zilles et al. (2005) reported that a lagoon receiving swine manure exhibited acceptable performance, that is, degradation of organic matter and nutrient removal, despite the presence of tetracycline and macrolide-lincosamide-streptogramin B $\left(\mathrm{MLS}_{\mathrm{B}}\right)$ antimicrobials at levels that would be expected to inhibit the growth of sensitive bacteria.

Tylosin, a macrolide antimicrobial commonly used in animal husbandry, inhibits protein synthesis by interacting with the 50S subunit of the bacterial ribosome (Mazzei et al., 1993). Reports on the inhibitory effects of tylosin on anaerobic treatment performance $(\mathrm{pH}$ levels from 6.9 to 7.8) appear contradictory (Angenent et al., 2008; Chelliapan et al., 2006; Loftin et al., 2005; Masse et al., 2000; Poels et al., 1984; Sanz et al., 1996). Studies of ASBRs treating swine manure indicated that the addition of tylosin to the influent (up to $16.7 \mathrm{mg} / \mathrm{L}$ ) had negligible effects on methane production and chemical oxygen demand (COD) removal efficiency (Angenent et al., 2008; Masse et al., 2000; Poels et al., 1984). A decrease in methane production was reported after addition of tylosin concentrations ranging from 1 to $25 \mathrm{mg} / \mathrm{L}$ in anaerobic batch reactors treating lagoon slurry collected from swine farms (Loftin et al., 2005). Partial inhibition of propionate and butyrate uptake was observed in anaerobic batch reactors with tylosin concentrations ranging from 25 to $250 \mathrm{mg} / \mathrm{L}$ (Sanz et al., 1996). Chelliapan et al. (2006) reported good treatment performance in an upflow anaerobic stage reactor (UASR) treating pharmaceutical wastewater with levels of tylosin up to $400 \mathrm{mg} / \mathrm{L}$ and observed a decrease in performance at higher tylosin concentrations.

The apparent contradictions observed in the studies presented above may be attributed to the history of the 
biomass, the tylosin concentration, the reactor configuration, and the methods used to evaluate performance. Longterm exposure to macrolide antimicrobials may result in the acclimation of the anaerobic biomass through the development of antimicrobial resistance or a microbial community shift towards less sensitive organisms, such as Gram-negative bacteria. Elevated levels of macrolide resistant organisms (40-70\%) have been reported in systems treating swine manure from farms with historic exposure to tylosin (Angenent et al., 2008; Jindal et al., 2006). The long hydraulic retention times (HRT) of 20 and 44 days in the studies by Poels et al. (1984) and Chelliapan et al. (2006), respectively, likely resulted in reactor concentrations of tylosin orders of magnitude lower than those in the influent due to the sorption and degradation of this antimicrobial (Angenent et al., 2008; Rabolle and Spliid, 2000). Among the studies presented above, only Sanz et al. (1996) evaluated the effects of tylosin on the uptake of volatile fatty acids. Studies that focus only on biogas production and COD removal may overlook the inhibition of specific groups of microorganisms in the anaerobic food web.

The purpose of this work was to study how anaerobic treatment performance is impacted by the presence of tylosin at concentrations relevant for animal production facilities. To this end, we operated a laboratory-scale ASBR fed a synthetic wastewater amended with tylosin at concentrations representative of waste streams from animal facilities with subtherapeutic and therapeutic usage.

\section{Materials and Methods}

\section{Laboratory-Scale ASBR}

A 7-L jacketed bioreactor with a 5-L working volume (Applikon Instruments Co., Schiedam, The Netherlands) was seeded using granular sludge from an upflow anaerobic sludge blanket (UASB) reactor treating brewery wastewater (Anheuser Busch Brewery, St. Louis, MO). The reactor was operated as a sequencing batch reactor (SBR) with 24-h cycles (10 min feeding, $23 \mathrm{~h} 40 \mathrm{~min}$ reaction, 1 min settling, and 9 min liquid withdrawal) with intermittent agitation (4 min every $20 \mathrm{~min}$ at $300 \mathrm{rpm}$ ) during the reaction step. Detailed information on the reactor setup has been described previously (Shimada et al., 2007a). The reactor was operated at $35^{\circ} \mathrm{C}$ with an organic loading rate (OLR) of $3.5 \mathrm{~kg} \mathrm{COD} /\left(\mathrm{m}^{3}\right.$ day), a hydraulic retention time (HRT) of 1.67 days, and a solids retention time (SRT) of 80 days. Stable operation was reached on day 320 of reactor operation. Sampling for cycle analyses was performed on days $600,650,749,860,880,900,1,000,1,010$, and 1,025 of reactor operation.

During the feeding step, $70 \mathrm{~mL}$ of a concentrated influent solution $\left(234.4 \mathrm{~g} / \mathrm{L}\right.$ glucose, $12.48 \mathrm{~g} / \mathrm{L} \mathrm{NH} \mathrm{NH}_{4} \mathrm{Cl}$, $0.5 \mathrm{~g} / \mathrm{L} \quad\left(\mathrm{NH}_{4}\right)_{2} \mathrm{SO}_{4}, \quad 1.66 \mathrm{~g} / \mathrm{L} \quad \mathrm{K}_{2} \mathrm{HPO}_{4}, \quad 1 \mathrm{~g} / \mathrm{L} \quad \mathrm{KH}_{2}$ $\mathrm{PO}_{4} \cdot \mathrm{H}_{2} \mathrm{O}, 0.5 \mathrm{~g} / \mathrm{L}$ yeast extract, and vitamins) was mixed with $2.93 \mathrm{~L}$ of dilution water $\left(3.45 \mathrm{~g} / \mathrm{L} \mathrm{NaHCO}_{3}, 1.725 \mathrm{~g} / \mathrm{L}\right.$
$\mathrm{KHCO}_{3}, 0.1 \mathrm{~g} / \mathrm{L} \mathrm{CaCl} 2 \cdot 2 \mathrm{H}_{2} \mathrm{O}, 0.1 \mathrm{~g} / \mathrm{L} \mathrm{MgCl}_{2} \cdot 6 \mathrm{H}_{2} \mathrm{O}$, and trace elements) (Shimada et al., 2007a). The dilution resulted in an average bicarbonate alkalinity of 2,564 \pm $21 \mathrm{mg} \mathrm{CaCO}_{3} / \mathrm{L}$ (mean \pm standard error) from days 320 to 600 of reactor operation. Tylosin was added separately from the concentrated influent solution and dilution water at influent concentrations of $1.67 \mathrm{mg} / \mathrm{L}$ (days 750-944) and $167 \mathrm{mg} / \mathrm{L}$ (days 945-1,040), which resulted in tylosin loading rates of 1 and $100 \mathrm{mg} \mathrm{L}^{-1} \mathrm{day}^{-1}$, respectively. The lower concentration was representative of manure slurry from swine farms with subtherapeutic usage of tylosin at a dosage of $20 \mathrm{~g}$ tylosin per $907 \mathrm{~kg}$ dry feed (Angenent et al., 2008). The higher concentration was considered representative of therapeutic usage and was estimated using the recommended dosage of $8.9 \mathrm{mg}$ tylosin per $\mathrm{kg}$ body weight per day and assuming $86 \mathrm{~kg}$ body weight per swine head, $99 \%$ excretion of tylosin, and $62 \mathrm{~L}$ of manure per $1,000 \mathrm{~kg}$ body weight per day.

\section{Batch Tests}

Specific biogas production (SBP) batch tests were conducted in triplicate with three levels of tylosin $(0,1$, and $100 \mathrm{mg} / \mathrm{L})$ and five substrate conditions (no substrate, glucose, acetate, propionate, and butyrate). Batch experiments were conducted in $125 \mathrm{~mL}$ glass bottles using a 16-cell AER-216 anaerobic respirometer (Challenge Environmental Systems, Springdale, AZ) and a multi-position magnetic stirrer with intermittent mixing ( $4 \mathrm{~min}$ every $20 \mathrm{~min}$ at $125 \mathrm{rpm}$ ). Each bottle was filled with $25 \mathrm{~mL}$ ASBR biomass and $35 \mathrm{~mL}$ dilution water containing carbonate buffer as described above and was capped with butyl-rubber septa. The headspace was flushed with a gas mixture of $\mathrm{CH}_{4}$ and $\mathrm{CO}_{2}(1: 1, \mathrm{v}: \mathrm{v})$. Each bottle received $2.5 \mathrm{~mL}$ of feed solution prepared with or without substrate $(37.3 \mathrm{mg}$ glucose $/ \mathrm{mL}, 32.7 \mathrm{mg}$ acetate $/ \mathrm{mL}, 23.2 \mathrm{mg}$ propionate $/ \mathrm{mL}$, or $19.2 \mathrm{mg}$ butyrate $/ \mathrm{mL}$ ) and was supplemented with nutrients, vitamins, and trace elements as described above. A volume of $5 \mathrm{~mL}$ of aqueous tylosin solution was added to each bottle resulting in concentrations of 0,1 , or $100 \mathrm{mg} / \mathrm{L}$. Biogas production was measured continuously. Statistical comparisons of means were performed using the Tukey method in SAS v8.1e (SAS Institute, Cary, NC).

\section{Analytical Methods}

COD, total solids (TS), volatile solids (VS), total suspended solids (TSS), and volatile suspended solids (VSS) were determined according to standard methods (American Public Health Association, 2000). Bicarbonate alkalinity was determined through a two-point titration method (Anderson and Yang, 1992). Concentrations of individual VFAs were determined with high performance liquid chromatography with UV detection at $210 \mathrm{~nm}$ (Waters, Milford, MA) using an Aminex HPX-87P cation exchange column (300 mm $\times 7.8 \mathrm{~mm}$ ID) (Bio-Rad Laboratories, Hercules, 
CA) (Amin et al., 2006). Glucose concentrations were determined using a hexokinase assay kit (Sigma-Aldrich, St. Louis, MO) according to the manufacturer's instructions. Total carbohydrates were extracted using the method described by Maurer et al. (1997) and analyzed for glucose as described above. The methane and hydrogen concentrations in the biogas were determined by gas chromatography (Shimada et al., 2007a).

\section{Results}

\section{Reactor Performance}

Operation of the ASBR with a 1.67-day HRT and a short settling time $(1 \mathrm{~min})$ resulted in good biomass settling conditions (granular biomass was maintained) and low effluent suspended solids (Fig. 1b) throughout the duration of the experimental period reported in this study. Prior to antimicrobial addition (Phase 1, days 600-749), the reactor exhibited excellent biogas production and soluble COD removal (Fig. 1). The mean daily biogas production for this period was $10.4 \pm 0.03 \mathrm{~L}$ (mean \pm standard error). Total and soluble COD concentrations in the effluent averaged $252 \pm 11 \mathrm{mg} / \mathrm{L}(95.7 \%$ removal $)$ and $26.6 \pm 2.1 \mathrm{mg} / \mathrm{L}$ (99.5\% removal), respectively. The TS concentration in the reactor was $28.3 \pm 0.4 \mathrm{~g} / \mathrm{L}$ (of which, on average, $82 \%$ consisted of VS). The mean TSS concentration in the effluent was $216 \pm 10 \mathrm{mg} / \mathrm{L}$ (of which, on average, $86 \%$ consisted of VSS). The mean effluent total VFA concentration was $20.1 \pm 2.1 \mathrm{mg} \mathrm{COD} / \mathrm{L}$.

Soluble COD removal and biogas production were not affected significantly $(P<0.05)$ by the addition of $1.67 \mathrm{mg} / \mathrm{L}$ tylosin to the ASBR influent (Phase 2, days 750944). However, a 46\% increase in effluent VSS (Fig. 1b) and a $9 \%$ decrease in the VS in the reactor (Fig. 1a) were observed. During this period, the mean daily biogas production was $10.3 \pm 0.02 \mathrm{~L}$. Total and soluble COD concentrations in the effluent averaged $367 \pm 19 \mathrm{mg} / \mathrm{L}$ (93.7\% removal) and $37.6 \pm 2.4 \mathrm{mg} / \mathrm{L}(99.3 \%$ removal), respectively. The TS concentration in the reactor was $26.2 \pm 0.3 \mathrm{~g} / \mathrm{L}$ ( of which, on average, $82 \%$ consisted of VS). The mean TSS concentration in the effluent was $300 \pm$ $16 \mathrm{mg} / \mathrm{L}$ (of which, on average, 90\% consisted of VSS). The mean effluent total VFA concentration was $21.3 \pm 1.5 \mathrm{mg}$ COD/L.
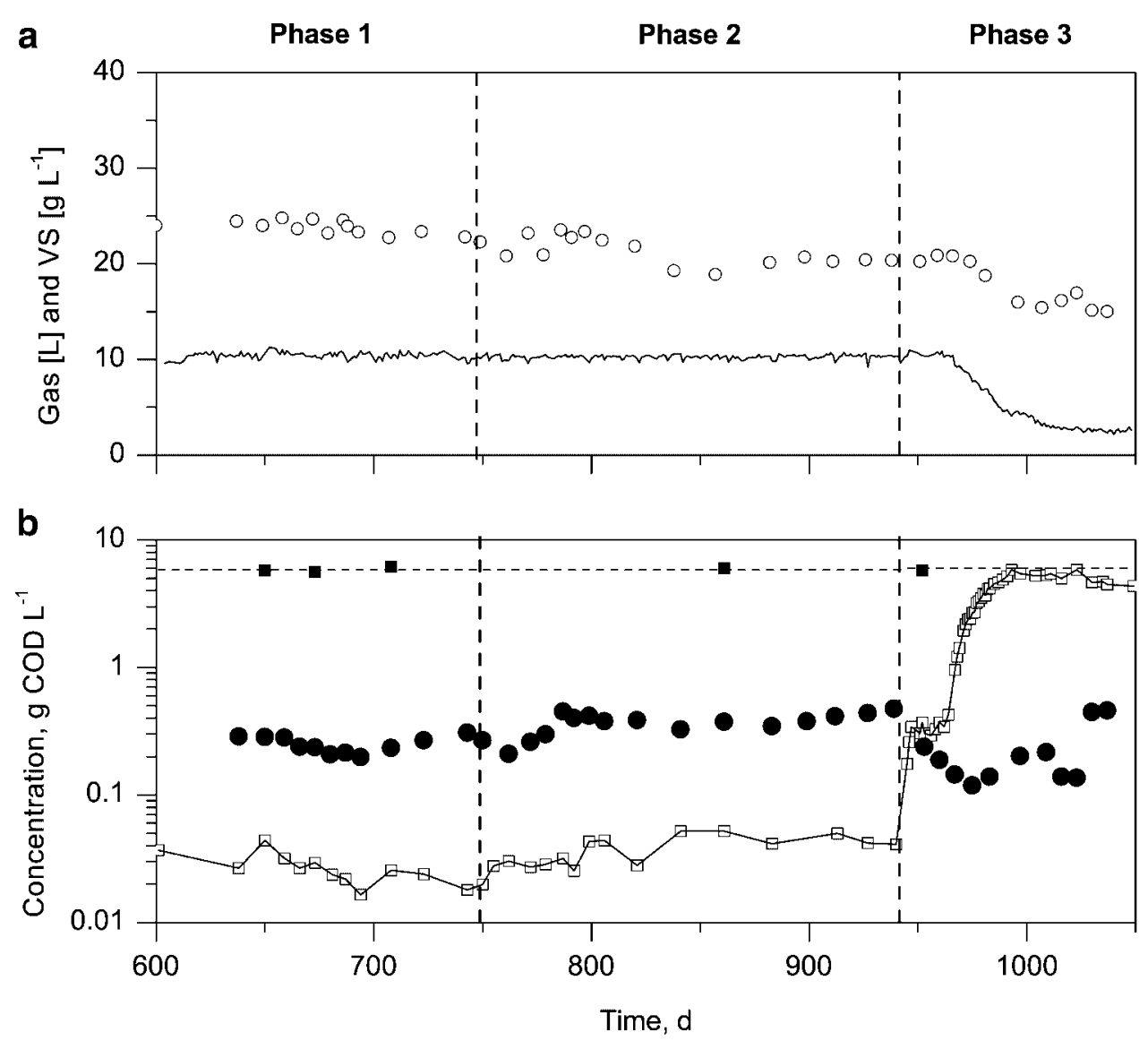

Figure 1. ASBR performance as (a) daily biogas volume (-) and reactor VS (O) and (b) target (- - -) and measured ( $\square$ ) influent COD, effluent soluble COD ( $\square$ ), and effluent VSS (O) during the operational periods without antimicrobial addition (Phase 1) and with influent tylosin concentrations of $1.67 \mathrm{mg} / \mathrm{L}$ (Phase 2) and 167 mg/L (Phase 3). 


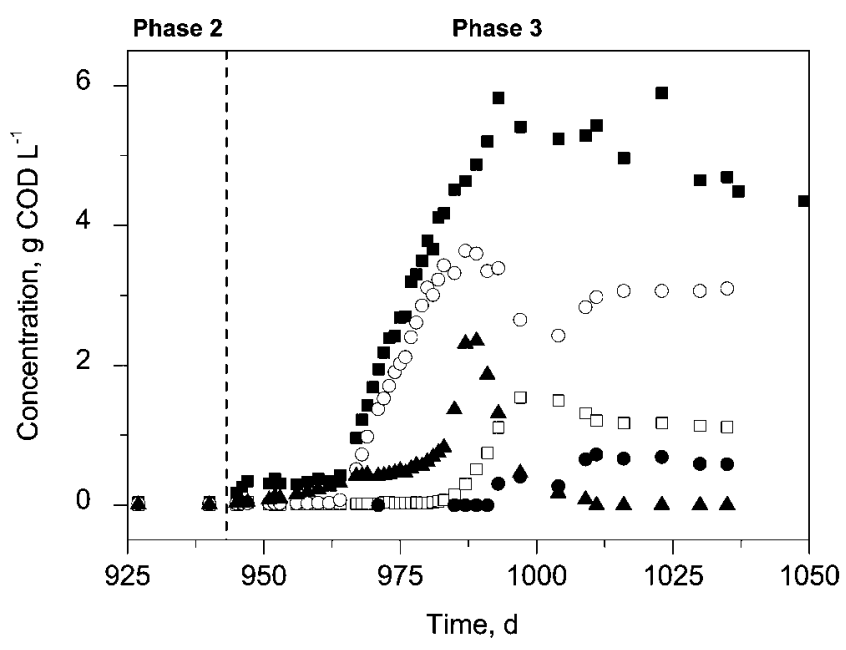

Figure 2. Concentrations of acetate $(\square)$, propionate $(O)$, succinate $(\bullet)$, caproate $(\boldsymbol{\Delta})$, and soluble $\operatorname{COD}(\boldsymbol{\square})$ in the ASBR effluent following the increase of influent tylosin concentration to $167 \mathrm{mg} / \mathrm{L}$ on day 945 .

Following a 20-day lag period, the addition of the higher concentration of tylosin in Phase 3 (days 945-1,040) resulted in a marked decrease in reactor performance (Fig. 1). An increase in the effluent soluble COD con- centration to $305 \pm 20 \mathrm{mg} / \mathrm{L}$ was observed immediately and was attributed to the presence of tylosin or its degradation products (167 mg tylosin/L=271 mg COD/L). Subsequently, reactor performance decreased substantially. Propionate and acetate accumulation in the effluent started on days 965 and 985, respectively (Fig. 2). Stable VFA concentrations were reached after day 1,000 with a mean daily biogas production of $2.9 \pm 0.07 \mathrm{~L}$ (values used to calculate means and standard errors for Phase 3 were for the period from day 1,000 to 1,039). Total and soluble COD concentrations in the effluent were $5,403 \pm 233 \mathrm{mg} /$ $\mathrm{L}(7 \%$ removal) and $5,126 \pm 175 \mathrm{mg} / \mathrm{L}(12 \%$ removal$)$, respectively. The TS concentration in the reactor was $20.9 \pm 0.4 \mathrm{~g} / \mathrm{L}$ (of which, on average, $76 \%$ consisted of VS). The mean TSS concentration in the effluent was $224 \pm 4 \mathrm{mg} / \mathrm{L}$ (of which, on average, 91\% consisted of VSS). The mean effluent total VFA concentration increased to $4,999 \pm 28 \mathrm{mg}$ COD/L. Propionate, acetate, caproate, succinate, and lactate accounted for $97 \pm 1 \%$ of the effluent soluble COD (Fig. 2).

\section{Cycle Analyses}

The dynamics of substrate conversion through the 24-h ASBR cycles were followed by continuously monitoring biogas production (Fig. 3). Although differences in daily
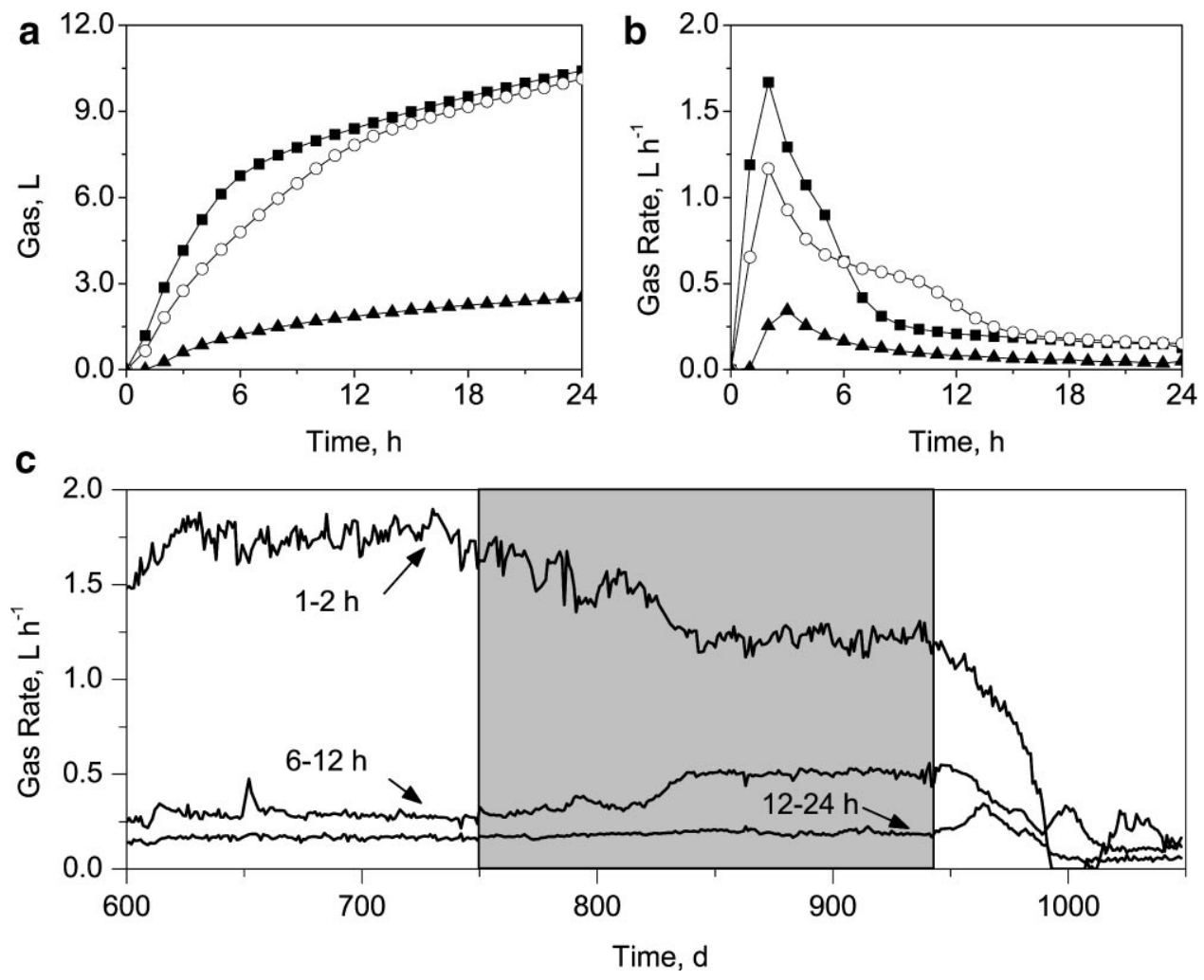

Figure 3. Average daily cumulative biogas production (a) and biogas production rate (b) throughout ASBR 24-h cycles during the periods without tylosin addition ( $\mathbf{\square}$ ) and with influent tylosin concentrations of $1.67 \mathrm{mg} / \mathrm{L}(\mathrm{O})$ and $167 \mathrm{mg} / \mathrm{L}(\mathbf{\Delta})$. Data points represent the mean of Phase 1 (days 600-749), Phase 2 (days 750-944), and Phase 3 (days 1,000-1,039). ASBR daily biogas production rates (c) averaged over different segments of the cycle: 1-2, 6-12, and 12-24 $\mathrm{h}$. 
biogas production between Phase 1 and Phase 2 were minor (Fig. 1), tylosin addition during Phase 2 resulted in a $30 \%$ decrease in the biogas production rate during the first $6 \mathrm{~h}$ of the cycle. During Phase 3, the daily biogas production was $68 \%$ lower and the biogas production rates decreased considerably.

To evaluate the kinetics of carbon flow in the reactor, glucose, individual VFAs, and methane were monitored during three 24-h cycles for each phase of ASBR operation (Fig. 4). The cycle analyses showed the dynamics of glucose utilization and accumulation of propionate and, to a lesser degree, acetate. The addition of $1.67 \mathrm{mg} / \mathrm{L}$ tylosin to the reactor in Phase 2 decreased the rates of propionate degradation and methane production but had no apparent effect on the glucose and acetate uptake rates. The increase of tylosin to $167 \mathrm{mg} / \mathrm{L}$ in Phase 3 caused the accumulation of VFAs (i.e., propionate and acetate) and a 96\% decrease in methane production. Propionate and acetate accumulation continued after the glucose had been depleted. A comparison between cycle analyses in Phase 3 (days 1,000, 1,010, and 1,025) showed a gradual increase in glucose and lactate uptake rates (Fig. 5). Glucose, acetate, and propionate accounted for all of the soluble COD in the reactor during Phase 1 and Phase 2. Lactate and succinate became important intermediates during Phase 3 (Fig. 2). Hydrogen accumulation was not substantial; during day 1,059, the
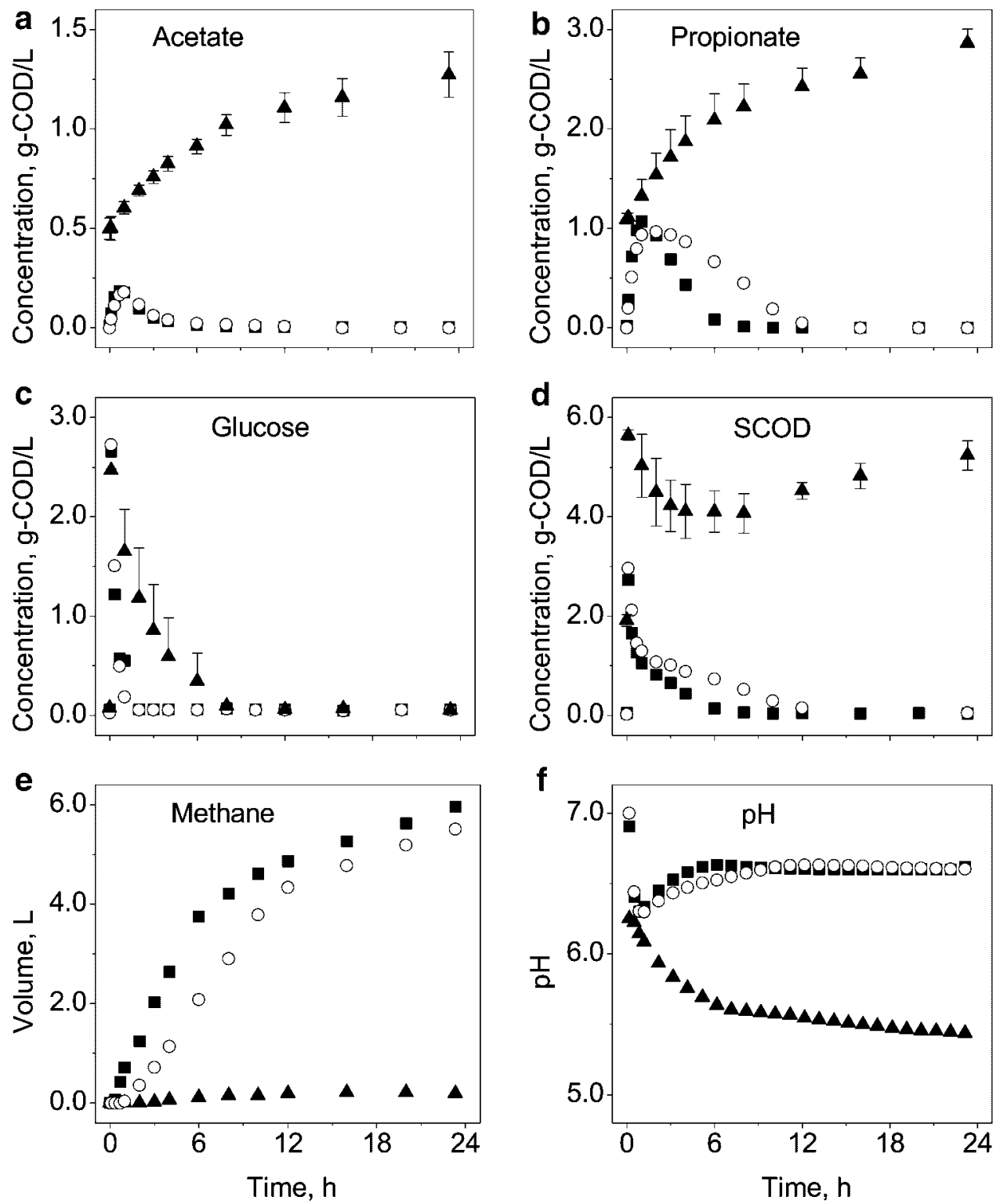

Figure 4. Concentrations of acetate (a), propionate (b), glucose (c), soluble COD (d), and biogas methane (e), and pH (f) in the ASBR throughout 24-h cycles during the periods without tylosin addition $(\boldsymbol{\square})$ and with influent tylosin concentrations of $1.67 \mathrm{mg} / \mathrm{L}(\bigcirc)$ and $167 \mathrm{mg} / \mathrm{L}(\mathbf{\Delta})$. Data points and error bars represent the mean and standard error of three cycles (days 600, 650, and 749 for Phase 1, days 860, 880, and 900 for Phase 2, and days 1,000, 1,010, and 1,025 for Phase 3), respectively. 

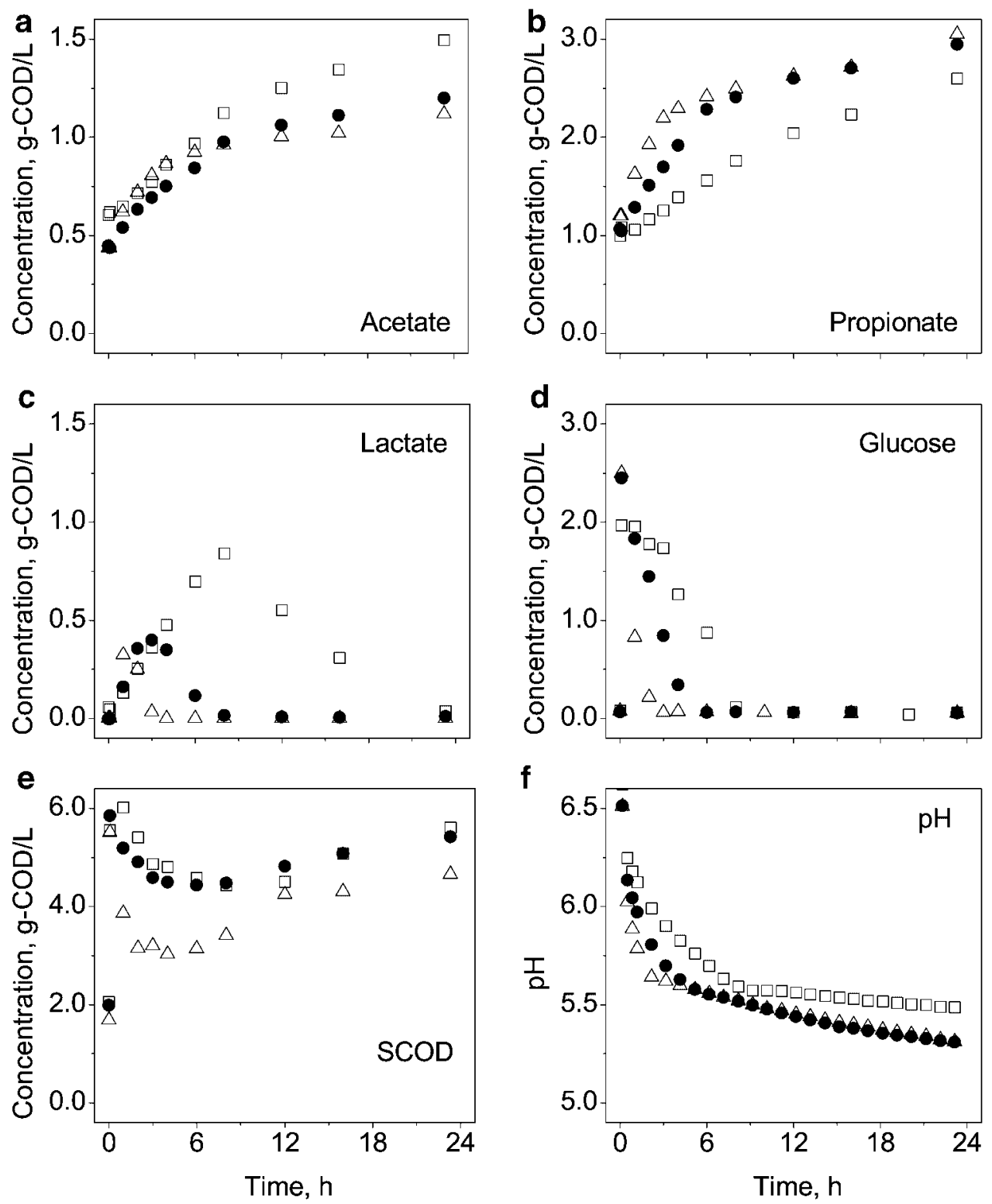

Figure 5. Concentrations of acetate (a), propionate (b), lactate (c), glucose (d), and soluble $\operatorname{COD}(\mathbf{e})$, and pH level (f) in the ASBR throughout 24-h cycles performed on days $1,000(\square), 1,010(\bullet)$, and $1,025(\triangle)$ of reactor operation with influent concentrations of $167 \mathrm{mg}$ tylosin/L. Data points represent averages of duplicate measurements.

maximum hydrogen gas concentration in the headspace was $220 \mathrm{ppm}$ and was reached $2 \mathrm{~h}$ after substrate addition.

Accumulation of reserve carbohydrates was an important process in the glucose-fed ASBR before the addition of tylosin (Shimada et al., 2007a). The effect of tylosin addition on microbial storage was investigated by measuring total carbohydrate concentrations throughout 24-h cycles. The initial total carbohydrate concentration increased after tylosin addition to the reactor. At the beginning of the 24-h cycles (i.e., before substrate addition), the mean total carbohydrate concentrations in the biomass were $74.5 \pm$ $3.4,125.5 \pm 11.2$, and 90.2 (only one measurement) $\mathrm{mg}$ COD/g VS for Phase 1, Phase 2, and Phase 3, respectively.
However, the amount of polysaccharide storage did not differ significantly $(P<0.05)$ between the three phases of reactor operation. Eight hours into the cycle, the total carbohydrate concentration in the biomass increased $37.2 \pm 9.4 \mathrm{mg} \mathrm{COD} / \mathrm{g} \mathrm{VS}, 22.4 \pm 16.3 \mathrm{mg} \mathrm{COD} / \mathrm{g} \mathrm{VS}$, and 18.2 (only one measurement) mg COD/g VS for Phase 1, Phase 2, and Phase 3, respectively.

\section{Batch Tests}

To evaluate the inhibitory effect of tylosin on specific trophic groups in the reactor, SBP batch tests were performed with ASBR biomass from Phase 1, Phase 2, 
Table I. Mean specific biogas production (SBP) rates for different batch test conditions using biomass from Phase 1 (days 310 and 556), Phase 2 (days 828 and 842), and Phase 3 (days 1,040 and 1,042) of the experimental period.

\begin{tabular}{|c|c|c|c|c|c|c|c|}
\hline \multirow[b]{3}{*}{ Substrate } & \multirow[b]{3}{*}{ Phase } & \multicolumn{6}{|c|}{ SBP rate $\left(\mathrm{mLg} \mathrm{VS}^{-1}\right.$ day $\left.^{-1}\right)$} \\
\hline & & \multicolumn{2}{|c|}{$0 \mathrm{mg}$ tylosin/L } & \multicolumn{2}{|c|}{$1 \mathrm{mg}$ tylosin/L } & \multicolumn{2}{|c|}{$\begin{array}{c}100 \mathrm{mg} \\
\text { tylosin/L }\end{array}$} \\
\hline & & Mean & SE & Mean & SE & Mean & SE \\
\hline \multirow[t]{3}{*}{ Control } & 1 & $15.92^{\mathrm{a}, \mathrm{x}}$ & 0.18 & $17.45^{\mathrm{a}, \mathrm{x}}$ & 2.62 & $16.44^{\mathrm{a}, \mathrm{x}}$ & 1.36 \\
\hline & 2 & $20.75^{\mathrm{b}, \mathrm{x}}$ & 0.02 & $21.11^{\mathrm{a}, \mathrm{x}}$ & 2.88 & $22.89^{\mathrm{a}, \mathrm{x}}$ & 1.49 \\
\hline & 3 & $4.25^{\mathrm{c}, \mathrm{x}}$ & 0.60 & $4.17^{\mathrm{b}, \mathrm{x}}$ & 0.75 & $3.77^{\mathrm{b}, \mathrm{x}}$ & 0.64 \\
\hline \multirow[t]{3}{*}{ Glucose } & 1 & $129.74^{\mathrm{a}, \mathrm{x}}$ & 1.30 & $130.17^{\mathrm{a}, \mathrm{x}}$ & 6.74 & $128.84^{\mathrm{a}, \mathrm{x}}$ & 1.60 \\
\hline & 2 & $114.02^{\mathrm{a}, \mathrm{x}}$ & 12.05 & $116.93^{\mathrm{a}, \mathrm{x}}$ & 2.40 & $118.66^{\mathrm{a}, \mathrm{x}}$ & 4.47 \\
\hline & 3 & $84.67^{\mathrm{a}, \mathrm{x}}$ & 1.23 & $83.92^{\mathrm{b}, \mathrm{x}}$ & 1.04 & $83.49^{\mathrm{b}, \mathrm{x}}$ & 3.07 \\
\hline \multirow[t]{3}{*}{ Acetate } & 1 & $74.25^{\mathrm{a}, \mathrm{x}}$ & 5.47 & $64.95^{\mathrm{a}, \mathrm{x}, \mathrm{y}}$ & 6.74 & $59.02^{\mathrm{a}, \mathrm{y}}$ & 0.28 \\
\hline & 2 & $96.41^{\mathrm{a}, \mathrm{x}}$ & 5.08 & $87.08^{\mathrm{b}, \mathrm{x}}$ & 2.40 & $84.00^{\mathrm{b}, \mathrm{x}}$ & 4.04 \\
\hline & 3 & $7.55^{\mathrm{b}, \mathrm{x}}$ & 1.19 & $7.38^{\mathrm{c}, \mathrm{x}}$ & 1.04 & $7.82^{\mathrm{c}, \mathrm{x}}$ & 1.13 \\
\hline \multirow[t]{3}{*}{ Propionate } & 1 & $94.19^{\mathrm{a}, \mathrm{x}}$ & 3.19 & $88.19^{\mathrm{a}, \mathrm{x}, \mathrm{y}}$ & 1.23 & $85.55^{\mathrm{a}, \mathrm{y}}$ & 0.81 \\
\hline & 2 & $76.62^{\mathrm{b}, \mathrm{x}}$ & 0.14 & $79.16^{\mathrm{a}, \mathrm{x}}$ & 2.53 & $80.15^{\mathrm{a}, \mathrm{x}}$ & 6.90 \\
\hline & 3 & $8.01^{\mathrm{c}, \mathrm{x}}$ & 0.48 & $7.36^{\mathrm{b}, \mathrm{x}}$ & 1.03 & $7.96^{\mathrm{b}, \mathrm{x}}$ & 0.07 \\
\hline \multirow[t]{3}{*}{ Butyrate } & 1 & $30.29^{\mathrm{a}, \mathrm{x}}$ & 0.36 & $21.75^{\mathrm{a}, \mathrm{y}}$ & 0.16 & $22.38^{\mathrm{a}, \mathrm{y}}$ & 0.24 \\
\hline & 2 & $25.82^{\mathrm{b}, \mathrm{x}}$ & 0.29 & $21.69^{\mathrm{a}, \mathrm{x}}$ & 0.18 & $24.33^{\mathrm{a}, \mathrm{x}}$ & 0.57 \\
\hline & 3 & $3.99^{\mathrm{c}, \mathrm{x}}$ & 0.17 & $4.32^{\mathrm{b}, \mathrm{x}}$ & 0.46 & $4.15^{\mathrm{b}, \mathrm{x}}$ & 0.33 \\
\hline
\end{tabular}

SE, standard error of duplicate experiments.

a,b,c Comparison of the three experimental phases with the same type of substrate and the same tylosin concentration. Tests with different superscripts differ significantly $(P<0.05)$.

${ }_{\mathrm{x}, \mathrm{y}, \mathrm{z}}$ Comparison of the three tylosin concentrations from tests within the same experimental phase and type of substrate. Tests with different superscripts differ significantly $(P<0.05)$.

and Phase 3 (Table I). A comparison within each phase showed that, in most cases, the concentration of tylosin in the batch tests did not have a significant effect $(P<0.05)$ on the SBP rate. However, the presence of tylosin resulted in a decrease in the SBP rate in some Phase 1 batch tests (butyrate at 1 and $100 \mathrm{mg} / \mathrm{L}$ tylosin and acetate and propionate at $100 \mathrm{mg} / \mathrm{L}$ tylosin).

In some cases, the SBP batch tests showed marked differences between the different operational periods of the ASBR (Table I). Differences between Phase 1 and Phase 2 were not significant $(P<0.05)$ in tests with the substrate glucose (all tylosin conditions) and tests with the substrates propionate and butyrate ( 1 and $100 \mathrm{mg}$ tylosin/L tests). In Phase 2, a significant $(P<0.05)$ increase of the SBP rate was observed for tests without substrate and tests with the substrate acetate. In Phase 3 , a significant $(P<0.05)$ decrease of the SBP rate for all test conditions was observed. Only the batch tests with the substrate glucose showed considerable biogas production in Phase 3; tests with the substrates acetate, propionate, and butyrate were not significantly $(P<0.05)$ different from the control.

\section{Discussion}

This study investigated how anaerobic treatment performance is affected by the presence of tylosin at concentrations relevant for animal production facilities. The results indicate that the effects of tylosin on microorganisms vary for the different populations of the anaerobic food web and are dependent on the concentration of the antimicrobial. Two types of inhibitory effects were observed, direct effects on sensitive microorganisms and indirect effects of accumulated intermediates on tylosin resistant microorganisms.

\section{Glucose Uptake}

The results of cycle analyses indicate that glucose fermentation in the ASBR was partially inhibited during addition of tylosin at a concentration of $167 \mathrm{mg} / \mathrm{L}$ (Fig. 4c); this is attributed to the accumulation of propionate and is therefore considered an indirect effect of tylosin. In a related study, we determined that propionibacteria constituted a major group of glucose fermenting bacteria in the ASBR (Shimada et al., 2007b). Resistance to macrolide antimicrobials is widespread among propionibacteria, with minimum inhibitory concentrations (MIC) of tylosin higher than $512 \mathrm{mg} / \mathrm{L}$ (Ross et al., 2002). Based on this information and our SBP batch test results, direct inhibition of glucose fermenting bacteria would not be expected. The observed accumulation of caproate (Fig. 2) would also not be expected to inhibit glucose fermentation, based on reported inhibitory concentrations for glucose fermenting bacteria. Caproate concentrations of up to $11 \mathrm{~g}-\mathrm{COD} / \mathrm{L}$ were not inhibitory to cultures of Clostridium perfringens (Skrivanova et al., 2005). However, high levels of propionate did inhibit the growth and metabolism of Propionibacterium thoenii, a glucose fermenting organism ( $\mathrm{Gu}$ et al., 1998). Propionate is believed to disrupt the gradient across the bacterial cell membrane when the undissociated acid diffuses into the cell and releases its proton into the cytoplasm (Herrero et al., 1985). Propionate and acetate accumulation in Phase 3 also caused a drop in the $\mathrm{pH}$, followed by the appearance of other intermediates: caproate, lactate, and succinate (Fig. 2 and Fig. 5c). These results agree with studies that have reported changes in the fermentation products produced from glucose under different $\mathrm{pH}$ conditions, ranging from 5 to 8 (Horiuchi et al., 2002). The inhibitory effects of VFAs are exacerbated at low $\mathrm{pH}$ so the combination of propionate accumulation and the $\mathrm{pH}$ drop in the reactor may have been responsible for the observed inhibition of glucose uptake.

The rate of glucose degradation in the reactor recovered gradually between days 1,000 and 1,025 of reactor operation (Fig. 5d). Potential explanations for the recovery include acclimation to lower $\mathrm{pH}$ and/or changes in the microbial community structure or level of antimicrobial resistance. Future microbial analysis may distinguish among these possibilities.

\section{Propionate and Butyrate Uptake}

Tylosin exerted inhibitory effects on butyrate and propionate degradation. These results support previous work in 
which inhibition of butyrate and propionate degradation was observed in the presence of macrolide antimicrobials at pH ranging from 7 to 8.5 (Amin et al., 2006; Sanz et al., 1996). The lack of detection of butyrate in the reactor and the low activity of butyrate degrading organisms in the SBP batch tests suggested that butyrate was not an important intermediate. However, inhibition of butyrate degradation was observed in SBP batch tests after tylosin was added. Degradation of butyrate and higher homologs is carried out by Gram positive beta-oxidizing syntrophic bacteria (e.g., Syntrophomonas spp. and Syntrophospora spp.), and tylosin would be expected to inhibit sensitive strains of this microbial group.

Propionate uptake in the ASBR was partially inhibited by tylosin at an influent concentration of $1.67 \mathrm{mg} / \mathrm{L}$ (Fig. 4b), which resulted in a decrease of the biogas production rate (Fig. 3). The propionate uptake rate continued to decline after the tylosin concentration was increased to $167 \mathrm{mg} / \mathrm{L}$ and led to the accumulation of propionate in the reactor (Fig. 2). The inhibition of propionate degradation likely was not due to the low $\mathrm{pH}$ conditions in Phase 3 since the reported range for growth of propionate oxidizing bacteria of the genus Syntrophobacter is 6.0-8.0 (Harmsen et al., 1998; Liu et al., 1999). Propionate started to accumulate on day 965 and reached a concentration of $6,260 \mathrm{mg} / \mathrm{L}$ before the $\mathrm{pH}$ decreased to a value of 6.0 on day 988 (data not presented). Negligible biogas production and propionate removal during SBP batch tests at neutral $\mathrm{pH}$ indicated that propionate oxidation was completely inhibited in Phase 3 (Table I). These results indicated the presence of tylosinsensitive propionate oxidizers.

One unexpected observation was the 20-day lag period between the increased addition of tylosin in Phase 3 and the accumulation of VFA (Fig. 2). One possible explanation for this lag would be slow transport of tylosin inside the granules. Intra-biofilm diffusion coefficients for hydrophobic organic compounds are orders of magnitude lower than those for aqueous diffusion (Wicke et al., 2007) and sorption may retard antimicrobial penetration into biofilms (Stewart, 1996), thus tylosin concentrations inside granules may take several days to reach equilibrium with the bulk liquid. Alternatively, a biological mechanism could be at work. Analyses of tylosin concentrations and microbial community composition may have allowed us to distinguish between abiotic and biological mechanisms for the observed lag, but those analyses were beyond the scope of the current study.

\section{Acetate Uptake}

Acetate uptake was not inhibited by tylosin addition during Phase 2. However, complete inhibition of acetate uptake and a marked decrease in methane production were observed during Phase 3. Several potential explanations for this result exist, including inhibitory effects of tylosin on homoacetogenic bacteria or aceticlastic methanogens and accu- mulation of organic acids to inhibitory levels, but an indirect $\mathrm{pH}$ effect on aceticlastic methanogens appears most likely. Homoacetogenic bacteria can convert acetate to hydrogen, providing substrate to hydrogen consuming methanogenic archaea, and inhibition of homoacetogenic bacteria has been proposed as an explanation for the inhibitory effects of macrolide antimicrobials on methanogenesis of acetate at neutral pH (Amin et al., 2006). However, in the current study, microbiological analyses indicated that acetateutilizing Methanosaeta spp. represented the major fraction of archaea in the reactor (Shimada et al., 2007b). Thus, homoacetogenic bacteria would not be expected to have an important role as acetate degraders. Archaea likely are not affected by tylosin since a number of nucleotides in its binding site on the 23S rRNA are different in bacteria and archaea (Auerbach et al., 2004; Garza-Ramos et al., 2001). Therefore, the inhibitory effect of tylosin is believed to be an indirect effect, and it could be mediated by the accumulation of toxic levels of intermediates, low production of acetate and/or hydrogen, or low $\mathrm{pH}$, all due to the accumulation of VFAs upon inhibition of syntrophic organisms. Acetate accumulation started on day 980 of ASBR operation, when the lowest $\mathrm{pH}$ within a 24 -h cycle had decreased to 6.0 (data not presented), and the propionate and caproate concentrations reached 3,100 $\mathrm{mg} \mathrm{COD} / \mathrm{L}$ and $700 \mathrm{mg} \mathrm{COD} / \mathrm{L}$, respectively (Fig. 2). Toxicity due to acetate, caproate, and propionate inhibition is not likely. Acetate does not inhibit methanogenic archaea (Kaspar and Wuhrmann, 1978). The maximum caproate and propionate levels were far below reported inhibitory concentrations of tens of g-COD/L for methanogenic archaea (Hajarnis and Ranade, 1994; Jarrell et al., 1987). Methanogenesis has also been observed in anaerobic systems with propionate concentrations above $4.15 \mathrm{~g}$ COD/L (Dhaked et al., 2003; Pullammanappallil et al., 2001). The $\mathrm{pH}$, however, was at the lower limit of the reported optimum $\mathrm{pH}$ range for most aceticlastic methanogens (Steinhaus et al., 2007) and continued to decrease with further accumulation of VFAs. The inhibition of acetate uptake is therefore attributed to the observed decrease in $\mathrm{pH}$.

\section{Polysaccharide Levels}

The soluble COD data from Phase 3 cycle analyses demonstrate the uptake of soluble COD at the beginning of the cycle followed by a subsequent recovery towards the end of the cycle (Fig. 5d). This recovery was due to acetate and propionate production that occurred after glucose depletion. These results support our previous findings on storage dynamics in ASBRs (Shimada et al., 2007a): during the feast stage of ASBR operation, $26 \%$ of the glucose added to the reactor was converted into the intermediate compound trehalose, which was subsequently converted into propionate and acetate during the famine stage of the SBR operation. The initial level of polysaccharides in Phases 2 and 3 was higher than the level in Phase 1 . This was most 
likely due to the production of extracellular polysaccharides in response to stress, not to an increase in storage, as it was not converted to VFAs.

\section{Conclusions}

Long-term exposure to tylosin inhibited butyrate and propionate oxidation in a glucose-fed ASBR and resulted in a decrease of acetate and glucose uptake and methane production, presumably through a $\mathrm{pH}$ effect. With extended operation, the utilization of glucose partially recovered but overall performance did not. Low tylosin concentrations decreased the propionate uptake kinetics without impacting overall reactor performance. High tylosin concentrations completely inhibited propionate uptake in the reactor. The inhibition of specific pathways in the anaerobic food web can lead to the accumulation of intermediates and negatively impact the overall system (low $\mathrm{pH}$ and/or toxicity) resulting in the breakdown of treatment performance.

Adaptation to toxic compounds in long term studies results in the underestimation of microbial inhibition, while short-term batch tests overlooked growth/decay related effects in slow growing anaerobic organisms. Thus, long term monitoring of reactors combined with short term toxicity batch tests are necessary to analyze the impact of antimicrobials on anaerobic systems.

We appreciate the helpful discussions with Hector Poggi-Varaldo of the Centro de Investigación y Estudios Avanzados (CINVESTAV), Mexico. Toshio Shimada was supported by a fellowship from the Consejo Nacional de Ciencia y Tecnología (CONACYT), Mexico. This research was partially supported by the U.S. Department of Agriculture under Cooperative Agreement AG 58-3620-1-179.

\section{References}

American Public Health Association, editor. 2000. Standard methods for the examination of water and wastewater. 20th edn. Washington, DC: American Water Works Association.

Amin MM, Zilles JL, Greiner J, Charbonneau S, Raskin L, Morgenroth E. 2006. Influence of the antibiotic erythromycin on anaerobic treatment of a pharmaceutical wastewater. Environ Sci Technol 40(12):39713977.

Anderson GK, Yang G. 1992. Determination of bicarbonate and total volatile acid concentration in anaerobic digesters using a simple titration. Water Environ Res 64(1):53-59.

Angenent LT, Mau M, George U, Zahn JA, Raskin L. 2008. Effect of the presence of the antimicrobial tylosin in swine waste on anaerobic treatment. Water Res doi:10.1016/j.watres.2008.01.005.

Auerbach T, Bashan A, Yonath A. 2004. Ribosomal antibiotics: Structural basis for resistance, synergism and selectivity. Trends Biotechnol 22(11):570-576

Campagnolo ER, Johnson KR, Karpati A, Rubin CS, Koplin DW, Meyer MT, Esteban JE, Currier RW, Smith K, Thu KM., et al. 2002. Antimicrobial residues in animal waste and water resources proximal to large-scale swine poultry feeding operations. Sci Total Environ 299:8995.

Chelliapan S, Wilby T, Sallis PJ. 2006. Performance of an up-flow anaerobic stage reactor (UASR) in the treatment of pharmaceutical wastewater containing macrolide antibiotics. Water Res 40(3):507-516.
Dhaked RK, Waghmare CK, Alam SI, Kamboj DV, Singh L. 2003. Effect of propionate toxicity on methanogenesis of night soil at phychrophilic temperature. Bioresour Technol 87:299-303.

Garza-Ramos G, Xiong L, Zhong P, Mankin A. 2001. Binding site of macrolide antibiotics on the ribosome: New resistance mutation identifies a specific interaction of ketolides with rRN. J Bacteriol 183(23): 6898-6907.

Gu Z, Glatz BA, Glatz CE. 1998. Effects of propionic acid on propionibacteria fermentation. Enzyme Microb Technol 22(1):13-18.

Hajarnis SR, Ranade DR. 1994. Inhibition of methanogens by $\mathrm{n}$ - and iso-volatile fatty acids. World J Microbiol Biotechnol 10(3):350-351.

Hamscher G, Sczesny S, Hoper H, Nau H. 2002. Determination of persistent tetracycline residues in soil fertilized with liquid manure by highperformance liquid chromatography with electrospray ionization tandem mass spectrometry. Anal Chem 74(7):1509-1518.

Harmsen HJM, Van Kuijk BLM, Plugge CM, Akkermans ADL, De Vos WM, Stams AJM. 1998. Syntrophobacter fumaroxidans sp nov, a syntrophic propionate-degrading sulfate-reducing bacterium. Int J Syst Bacteriol 48:1383-1387.

Herrero AA, Gomex RF, Snedecor B. 1985. Growth inhibition of Clostridium thermocellum by carboxylic acids: A mechanism based on uncoupling by weak acids. Appl Microbiol Biotechnol 22:53-60.

Horiuchi JI, Shimizu T, Tada K, Kanno T, Kobayashi M. 2002. Selective production of organic acids in anaerobic acid reactor by $\mathrm{pH}$ control. Bioresour Technol 82:209-213.

Jarrell K, Saulnier M, Ley A. 1987. Inhibition of methanogenesis in pure cultures by ammonia, fatty acids, and heavy metals, and protection against heavy metal toxicity by sewage sludge. Can J Microbiol 33(6): 551-554.

Jindal A, Kocherginskaya S, Mehboob A, Robert M, Mackie RI, Raskin L, Zilles JL. 2006. Antimicrobial resistance in swine waste treatment systems. Appl Environ Microbiol 72(12):7813-7820.

Kaspar HF, Wuhrmann K. 1978. Product inhibition in sludge digestion. Microb Ecol 4(3):241-248.

Liu YT, Balkwill DL, Aldrich HC, Drake GR, Boone DR. 1999. Characterization of the anaerobic propionate-degrading syntrophs Smithella propionica gen. nov., sp. nov. and Syntrophobacter wolinii. Int J Syst Bacteriol 49:545-556.

Loftin KA, Henny C, Adams CD, Surampali R, Mormile MR. 2005. Inhibition of microbial metabolism in anaerobic lagoons by selected sulfonamides, tetracyclines, lincomycin, and tylosin tartrate. Environ Toxicol Chem 24(4):782-788.

Masse DI, Lu D, Masse L, Droste RL. 2000. Effect of antibiotics on psychrophilic anaerobic digestion of swine manure slurry in sequencing batch reactors. Bioresour Technol 75(3):205-211.

Maurer M, Gujer W, Hany R, Bachmann S. 1997. Intracellular carbon flow in phosphorus accumulating organisms for activated sludge systems. Water Res 31:907-917.

Mazzei T, Mini E, Novelli A, Periti P. 1993. Chemistry and mode of action of macrolides. J Antimicrob Chemother 31 (Suppl. C): 1-9.

Poels J, Vanassche P, Verstraete W. 1984. Effects of disinfectants and antibiotics on the anaerobic-digestion of piggery waste. Agric Wastes 9(4):239-247.

Pullammanappallil PC, Chynoweth DP, Lyberatos G, Svoronos SA. 2001. Stable performance of anaerobic digestion in the presence of a high concentration of propionic acid. Bioresour Technol 78:165-169.

Rabolle M, Spliid NH. 2000. Sorption and mobility of metronidazole, olaquindox, oxytetracycline and tylosin in soil. Chemosphere 40(7): 715-722.

Ross JI, Eady EA, Carnegie E, Cove JH. 2002. Detection of transposon Tn5432-mediated macrolide-lincosamide-streptogramin $\mathrm{B}\left(\mathrm{MLS}_{\mathrm{B}}\right)$ resistance in cutaneous propionibacteria from six European cities. J Antimicrob Chemother 49:165-168.

Sanz JL, Rodriguez N, Amils R. 1996. The action of antibiotics on the anaerobic digestion process. Appl Microbiol Biotechnol 46(5-6):587-592.

Shimada T, Zilles J, Raskin L, Morgenroth E. 2007a. Carbohydrate storage in anaerobic sequencing batch reactors. Water Res 41(20):47214729 . 
Shimada T. 2007. Effects of macrolide antimicrobials on anaerobic treatment systems. Ph.D thesis, University of Illinois at Urbana-Champaign. $127 \mathrm{p}$.

Skrivanova E, Marounek M, Dlouha G, Kanka J. 2005. Susceptibility of Clostridium perfringens to $\mathrm{C}_{2}-\mathrm{C}_{18}$ fatty acids. Lett Appl Microbiol 41:77-81.

Steinhaus B, Garcia ML, Shen AQ, Angenent LT. 2007. A portable anaerobic microbioreactor reveals optimum growth conditions for the methanogen Methanosaeta concilii. Appl Environ Microbiol 73(5):16531658.
Stewart PS. 1996. Theoretical aspects of antibiotic diffusion into microbial biofilms. Antimicrob Agents Chemother 40(11):2517-2522.

Wicke D, Bockelmann U, Reemtsma T. 2007. Experimental and modeling approach to study sorption of dissolved hydrophobic organic contaminants to microbial biofilms. Water Res 41(10):22022210 .

Zilles J, Shimada T, Jindal A, Robert M, Raskin L. 2005. Presence of macrolide-lincosamide-streptogramin B and tetracycline antimicrobials in swine waste treatment processes and amended soil. Water Environ Res 77(1):57-62. 